taustainen koulutettu hoitohenkilökunta sosiaali- ja terveydenhuollon työyhteisöissä. Tehyn julkaisusarja B: 1/12 selvityksiä. Helsinki: Tehy.

LAAKSONEN, KAINO 2011: Ymmärrettävämpiä tekstejä Kelasta. - Kielikello 4/2011.

Laki lasten päivähoidosta annetun lain muuttamisesta 2015/580. https://www.finlex.fi/ fi/laki/alkup/2015/2015058o (28.5.2018).

Laki sosiaalihuollon asiakasasiakirjoista 2015/254. https://www.finlex.fi/fi/laki/ alkup/2015/20150254 (28.5.2018).

Lastensuojelulaki 2007/417. https://www. finlex.fi/fi/laki/alkup/2007/20070417 (28.5.2018).

Lehtinen, Essi 2008: Kertomuksia lapsista ja lasten määristä - Virastojen toimintakertomusten muutoksia.
- Kielikello 4/2008.

Рyнäniemi, SaIja 2010: Päiväkotien kirjoitustyöt: mitä, miten, milloin?

- Kielikello 1/2010.

Tillilä, Ulla 2007: Tekstit viraston työssä. Tutkimus etuuspäätösten kielestä ja konteksteista. Helsinki: Suomalaisen Kirjallisuuden Seura. 2011: Sanoilla lavastettu virasto. Tietoyhteiskunnan arkea sosiaali- ja hoivaaloilla. - Marjut Johansson, Pirkko Nuolijärvi \& Riitta Pyykkö (toim.), Kieli työssä. Asiantuntijatyön kielelliset käytännöt s. 162-189. Helsinki: Suomalaisen Kirjallisuuden Seura.

Vierula, TARJA 2017: Lastensuojelun asiakirjat vanhempien näkökulmasta. Tampere: Tampereen yliopisto. http:// urn.fi/URN:ISBN:978-952-03-0565-9.

\title{
Suomenruotsin murteista, vaihtelusta ja muuttuvasta kielimaisemasta
}

Ann-Marie Ivars: Dialekter och småstadsspråk. Svenskan i Finland - i dag och i går I:1. Skrifter utgivna av Svenska litteratursällskapet i Finland 798. Helsingfors:

Svenska litteratursällskapet i Finland 2015. 464 s. ISBN 978-951-583-336-5.

Marika Tandefelt (toim.): Gruppspråk, samspråk, två språk. Svenskan i Finland - i dag och i går l:2. Skrifter utgivna av Svenska litteratursällskapet i Finland 799. Helsingfors: Svenska litteratursällskapet i Finland 2015. 252 s. ISBN 978-951-583-337-2.

Tässä kirjoituksessa arvioitavat teokset ovat kaksi ensimmäistä kuusiosaisesta kirjasarjasta Svenskan i Finland - i dag och i går. Sarjan neljä ensimmäistä osaa on jo julkaistu (ks. myös Hiidenmaa tässä numerossa), kaksi osaa on suunniteltu julkaistavaksi vuonna 2019. Kirjasarja on tulosta samannimisestä hankkeesta (20102017), jonka suurin rahoittaja on Svenska litteratursällskapet i Finland (SLS). Projektin tavoitteena on esittää kattava kuvaus suomenruotsista sen erilaisissa puhutuissa ja kirjoitetuissa muodoissa sekä tuoda esiin niitä ominaisuuksia, joita suomenruotsilla on niin kutsuttuna monikeskuksisena kielenä (samaa kieltä puhutaan kahdessa tai useammassa maassa jossain määrin omina standardoituina varieteetteinaan). Tarkoituksena ei ole kuvata vain nykyistä suomenruotsia vaan muodostaa käsitys myös siitä, miten suomenruotsi on muuttunut aikojen kuluessa. 
Projektin tulokset perustuvat pääosin aiempien tutkimusten synteesiin. Kirjasarjan lisäksi tuloksena on suomenruotsalaisen digitaalisen tekstiarkiston laajennos (den finlandssvenska språkbanken).

Arvioin seuraavassa ensin Ann-Marie Ivarsin teoksen Dialekter och småstadsspråk ja sen jälkeen Marika Tandefeltin toimittaman teoksen Gruppspråk, samspråk, två språk. Kuvailen teosten keskeisen sisällön ajatellen erityisesti sellaista lukijaa, jonka tietämys suomenruotsista, sen murteista ja muusta vaihtelusta ei ole kovin suurta. Kommentoin samalla niitä vahvuuksia ja puutteita, joita teoksissa mielestäni on. Koska Ivarsin teos on varsin laaja, arvioni pääpaino on sen tarkastelussa.

\section{Suomenruotsin murteista ja puhutun kielen sosiaalisesta vaihtelusta}

Ann-Marie Ivars on pohjoismaisten kielten emeritaprofessori Helsingin yliopistossa. Hän on erikoistunut suomenruotsin murteisiin, niiden historiaan ja puhutun suomenruotsin sosiaaliseen vaihteluun. Ivars lähestyy vertaisarvioidussa teoksessaan suomenruotsin murteita seuraavista näkökulmista: (i) Miten suomenruotsi ja sen murteet ovat syntyneet ja muuttuneet? (ii) Millaisiin ryhmiin suomenruotsin murteita on jaettu ja jaetaan? (iii) Millaista alueellista ja sosiaalista vaihtelua suomenruotsissa on nykyään? Teos perustuu runsaaseen pariin sataan monografiaan ja tieteelliseen artikkeliin 180o-luvun lopulta 2010-luvulle. Näistä Ivars itse on kirjoittanut parikymmentä. Kirjallisuuden ohella taustalla ovat murrenauhoitukset, joista varhaisimmat on tehty 1950-luvun alussa ja tuoreimmat vuonna 2008. Empiirisesti teoksen perusta on siis vaikuttava.

Aluksi Ivars käsittelee murteen ja yleiskielen suhdetta, murteiden asemaa yhteiskunnassa sekä puhujien käsityksiä murteista (luku 1). Tämän jälkeen hän tarkastelee ruotsin kielen historiaa Suomessa, suomenruotsin piirteitä suhteessa Skandinaviassa puhuttaviin kielimuotoihin ja suomenruotsin päämurreryhmien (ns. eteläiset ja pohjoiset murteet) historiallista taustaa (luku 2). Luvuissa 3-6 hän kuvaa alueellisia päämurteita. Luvussa 7 kirjoittaja käsittelee suomenruotsin kaupunkikieliä (småstadsspråk) alueellisen ja sosiaalisen vaihtelun näkökulmista. Teoksen päätteeksi Ivars pohtii murteiden ja kaupunkikielten kehitystä (luku 8).

Kirjan pääpaino on perinteisissä murteissa (traditionella dialekter), minkä takia pääaineiston muodostavat vuosina 1952-1982 tehdyt nauhoitukset (s. 16). Aineiston puhujat edustavat pääosin 1800ja 1900-lukujen taitteessa syntyneitä ikäluokkia, joiden puheessa perinteiset murteet elivät vielä vahvoina. Murteiden tasoittumisen myötä kirjassa kuvataankin pääosin sellaisia kielimuotoja, jotka ovat vaarassa hävitä.

Ivarsin mukaan murteet ovat suomenruotsin vanhinta kielellistä perintöä (s. 48). On kiistanalaista, kuinka kauan Suomessa on puhuttu ruotsia, mutta useimmat arvioijat - myös Ivars - kallistuvat sille kannalle, että historia ulottuu noin tuhannen vuoden päähän. Ruotsin kielen toivat Suomeen maahanmuuttajat, jotka olivat kotoisin pääosin nykyisten Smålandin ja Hälsinglandin maakuntien väliseltä alueelta (s. 53). Eniten yhteisiä piirteitä suomenruotsilla on Itä-Sveanmaan eli Keski-Ruotsin pohjoisten murteiden kanssa (uppsvenska mål), joita puhutaan Upplandissa ja Gästriklandissa (s. 51). Suomeen tulijoiden maantieteellisestä taustasta kielivät ääntämykselliset ja sanastolliset seikat, esimerkiksi metsämansikkaa tarkoittava sana smultron, joka on Sveanmaan murteille ja suomenruotsille yhteinen (s. 54, kartta 3).

Ivarsin mukaan vaikuttaa siltä, että muuttoliike Suomeen on alkanut aikaisintaan 9oo-luvulla jKr. Arviota tukevat sellaiset suomenruotsin murteiden piirteet, joita tiedetään olleen tuon ajan murteissa 
Keski-Ruotsissa ja jotka olisivat siis tulleet muuttajien mukana maahamme. Tällainen piirre on esimerkiksi Birkassa (viikinkiaikainen yhteisö ja tärkeä kauppapaikka nyk. Tukholman lähellä) puhutun ruotsin diftongi ( $\ddot{a}>$ jä: här > jär, muinaisruotsin hiär), jonka katsotaan syntyneen Keski-Ruotsin murteisiin uutena piirteenä kielikontaktien vaikutuksesta 90o-luvulle tultaessa (s. 56). Suomenruotsin murteissa ei sen sijaan tapahtunut sitä vokaalien monoftongiutumista, jonka katsotaan toteutuneen Keski-Ruotsissa 1200-luvulle tultaessa ( $a i>e$, au ja $\ddot{y} y>\ddot{o}$; s. 57-59). Nämä havainnot puhuvat sen puolesta, että muuttoliike Suomeen olisi tapahtunut 1000-1200-luvuilla, mutta jyrkkää kantaa kysymykseen Ivars ei ota, sillä monoftongiutumisen ajallinen paikantaminen on vaikeaa (s. 59). Muuttoliikkeen ajallista paikantamista äänteenmuutoksia tarkastelemalla vaikeuttaa lisäksi se, että merkityksiä erottavaa aksenttioppositiota ei suomenruotsin murteissa esiinny. Aksenttioppositiossa intonaatio erottaa muutoin samanlaisia sanoja toisistaan: $a^{\prime} n d e n$ (aksentti 1, 'sorsa') mutta $a^{\prime}$ 'nden (aksentti 2, 'henki'). Keski-Ruotsin murteisiin aksenttiopposition katsotaan kehittyneen 90o-luvulta alkaen (s. 6o), ja siten opposition pitäisi esiintyä suomenruotsinkin murteissa, mikäli muutto olisi tapahtunut 1000-1200-luvuilla. Aksenttien puuttuminen suomenruotsista johtunee kuitenkin kontaktista suomeen: jos oppositio on murteissa esiintynytkin, se on niistä hävinnyt suomen vaikutuksesta (s. 61). Tämän puolesta puhuu sekin, että Länsi-Uudellamaalla oppositio esiintyi merkityksiä erottavana vielä 1970-luvulla (s. 284-285). Foneettisena piirteenä aksenttia esiintyy edelleen Pohjanmaan murteissa, muun muassa Oravaisissa ja Närpiössä (s. 83). Tämä tarkoittaa sitä, että intonaatio ei näissä murteissa erota sanojen merkityksiä systemaattisesti. Se ei siis ole prosodeemi, vaan oletettu foneettinen jäänne aiemmin vallinneesta fonologisesta aksenttioppositiosta.
Luvun 2 historiallinen taustaosio on mainio: se auttaa lukijaa ymmärtämään suomenruotsin murteiden syntyä ja myöhempää kehitystä. Lisäksi se valottaa hyvin sitä, miten äänteenmuutoksia tutkimalla voidaan saada tietoa kaukaisistakin historian tapahtumista. Samalla Ivars tunnustaa ne epätarkkuudet ja epävarmuudet, jotka liittyvät äänteenmuutosten ajalliseen paikantamiseen sekä siihen, millaisia johtopäätöksiä niistä voi tehdä.

\section{Murteellinen vaihtelu ja päämurrealueet}

Ivars jakaa suomenruotsin kolmeen tasoon sen mukaan, kuinka voimakkaita murrepiirteet ovat. Tasot ovat (i) paikallinen murre, (ii) paikallinen kaupunkikieli ja/tai alueellinen murre sekä (iii) alueellinen standardikieli eli niin kutsuttu finlandssvenska (s. 22). Standardikieli kehittyi Turussa $1600-$ luvulta alkaen KeskiRuotsin yleiskielen ja suomenruotsin murteiden, erityisesti Turussa käytetyn varieteetin, perustalle (s. 438). Paikalliset kaupunkikielet ovat puolestaan uusimpia, 1900-luvulla syntyneitä puhekielen muotoja. Niitä esiintyy sellaisissa kaupungeissa, joissa paikallisen murteen ja standardin ero on suuri. Ivarsin mukaan suomenruotsissa ei ole ylintä tasoa (maximal standard, s. 22), kuten on Ruotsissa. Tällä Ivars tarkoittanee sitä, että vaikka puhuja käyttäisikin alueellista standardikieltä, hänen saattaa kuulla tulevan joltain päämurrealueelta: Uudeltamaalta, Turunmaalta, Pohjanmaalta tai Ahvenanmaalta (s. 445). Tämä ei kuitenkaan viimeaikaisten tutkimusten valossa pidä välttämättä paikkaansa, koska kuulijoilla saattaa olla huomattavia vaikeuksia paikallistaa puhujia edes maakunnan tarkkuudella, mikäli nämä käyttävät yleiskieltä (Leinonen \& Henning-Lindblom 2016: 102, 105). Lisäksi Ivarsin argumentaatio jää sikäli heikoksi, että hän itsekin vertaa murteita standardikieleen $(\mathrm{mm}$. 
s. 21), jonka hän mainitsee muistuttavan eniten Keski-Uudellamaalla puhuttavaa alueellista standardia (s. 354)

Teoksen mukaan suomenruotsissa on (tai on ollut viime vuosikymmeniin asti) noin 80 paikallista murretta eli pitäjänmurretta (sockenmål, s. 14, kartta 1). Pitäjänmurteet syntyivät keskiajalla alkaneesta murteiden jakaantumisesta pitäjäjaon mukaan. Sana socken tuleekin verbistä söka ('etsiä, hakeutua'); saman pitäjän asukkaat hakeutuivat samaan kirkkoon ja samoille käräjille (s. 49). Jos mukaan lasketaan 1900-luvulla syntyneet kaupunkivarieteetit (lokala stadsmål), suomenruotsissa on noin sata puhutun kielen alueellista tai sosiaalisesti värittynyttä muotoa. Monia suomenruotsin murteita leimaavat äännejärjestelmän arkaistiset piirteet, esimerkiksi keskiajalta peräisin olevat diftongit ja tavukestot. Arkaististen piirteiden ja uusien piirteiden suhde kuitenkin vaihtelee murteesta toiseen (s. 78-80).

Kirjassa käsitellään ansiokkaasti murteita sosiolingvistisestä näkökulmasta, muun muassa puhujien ryhmäytymisen ja identifikaation kannalta (s. 23-39; luvut 7 ja 8). Murteiden luokittelun kielelliseen ongelmallisuuteen puututaan sen sijaan niukemmin. Koska murteet muodostavat jatkumon, kirjoittaja olisi voinut pohtia tarkemmin, millaisin perustein jatkumo jaetaan osiin: mitkä kielimuodot ovat samaa, mitkä eri murretta? Jos perusteena käytetään havaittavaa eroa murteiden välillä, esimerkiksi kaikki Pohjanmaan murteet eivät täytä määritelmää. Ivars itsekin toteaa (s. 76), että Kristiinankaupungin Siipyyn ja Kokkolan välillä puhutaan (tai on puhuttu) perinteisen luokittelun mukaan noin 30 :tä eri murretta, joista monet eivät kuitenkaan eroa niin paljon toisistaan, että niitä voisi pitää omina murteinaan. Kirjassa ne kuitenkin esitellään sellaisina, mikä on ristiriitaista ja antaa hiukan liioitellunkin kuvan murteiden määrästä.

Luvuissa 3-6 esitellään päämurrealueet ja niiden murteet. Päämurrealueita erote- taan neljä: Uusimaa, Turunmaa, Pohjanmaa ja Ahvenanmaa. Jokaisen alueen murteita käsitellään 50-100 sivun verran. Monin paikoin käsittely on yksityiskohtaista mutta pääosin lukijaystävällistä, kiitos etenkin runsaiden esimerkkien ja karttojen. Murteista esitellään foneemisto, prosodiaa (erityisesti sanaintonaatiota ja tavukestoja), morfologiaa sekä sanaston ja syntaksin piirteitä. Tarkkuudeltaan käsittely on väistämättä epätasaista, koska murteita on tutkittu vaihtelevasti. Yleiskuvan antamiseksi esittelen seuraavassa keskeisiä piirteitä kultakin päämurrealueelta.

Pohjanmaan murteissa (mm. Siipyy, Närpiö, Kokkola, Alaveteli ja Pietarsaari) on vahvoja ominaispiirteitä ääntämisessä ja morfologiassa. Murteita leimaavat arkaistiset piirteet, muun muassa Alavetelissä diftongit (njöut, vrt. yleiskielen njöt) ja lyhyttavuisuus ( $v i k a ̊$, vrt. yleiskielen vecka). Toisaalta murteissa esiintyy myös uusia piirteitä. Eräs mielenkiintoinen piirre on substantiivien yksisukuisuus Kokkolassa ja Alavetelissä; yksikön epämääräisessä muodossa kaikki substantiivit ovat en-sukua: ein häst, ein får (vrt. yleiskielen en häst, ett får). Suomen kielellä on saattanut olla vaikutusta kehitykseen, koska monen murteen puhujan ensikieli on luultavasti ollut suomi (s. 88). Pohjanmaan murteita leimaa myös prosodinen samankaltaisuus tiettyihin Ruotsin murteisiin nähden. Tällaisia piirteitä Ivars mainitsee olevan erityisesti sanaintonaatiossa, esimerkkinä aiemmin mainittu foneettinen sana-aksentti (s. 82-83). Muun kuin sanaintonaation osalta prosodinen samankaltaisuus jää kuitenkin tarkentamatta. Joillain paikkakunnilla vallitsee selvä sosiolingvistinen jako: esimerkiksi Pietarsaaressa paikallista murretta (Jakobstadsspråk) puhuvat vähemmän koulutetut aikuiset ja nuoriso, kun taas korkeammin koulutetut aikuiset käyttävät (alueellista) standardimuotoa (s. 364-365). Nuorison identifioituminen paikalliseen murteeseen on yllättävää ja 
antaa toivoa siitä, ettei murteiden tasoittuminen tai jopa häviäminen ole ainoa mahdollinen kehityssuunta (s. 380, 400, 436). Nämä sosiolingvistiset tulokset ja pohdinnat ovat hyvin mielenkiintoisia.

Uudenmaan murteet Ivars jakaa läntisiin, keskisiin ja itäisiin. Läntisiä murteita (västnyländska dialekter) puhutaan muun muassa Tammisaaressa, Karjaalla, Lohjalla ja Inkoossa. Murteita leimaa (tai leimasi aiemmin) sana-aksenttioppositio, joka muista suomenruotsin murteista puuttuu. ${ }^{1}$ Keski-Uudenmaan murteet (mellannyländska dialekter, mm. Kirkkonummi, Espoo, Vantaa ja Helsinki, vaikka viimeksi mainittua ei kirjassa käsitelläkään) ovat lähimpänä yleiskieltä (s. 354). Tällä alueella murteiden tasoittuminen on edennyt pisimmälle, ja useat alueen murteita aiemmin leimanneet piirteet ovat hävinneet tai häviämässä. Itä-Uudenmaan murteet (östnyländska dialekter, mm. Porvoo, Loviisa, Pyhtää ja Ruotsinpyhtää) ovat vahvimpia Uudellamaalla puhuttavista murteista. Murteille leimallisia ovat vanhat diftongit (veit vrt. vet, röykt vrt. rökte, höugär vrt. hög; s. 320). Myös muinaisruotsin substantiivijako kolmeen sukuun - maskuliini, feminiini ja neutri - on säilynyt ItäUudellamaalla paremmin kuin Keski- ja Länsi-Uudellamaalla (s. 328). Loviisassa on samankaltainen sosiolingvistinen jakauma kuin Pietarsaaressa: murretta puhuvat nuoriso ja vähemmän koulutetut, (alueellista) standardimuotoa taas korkeammin koulutetut.

Ahvenanmaan murteet (åländska dialekter) jaetaan teoksessa läntisiin ja itäisiin. Läntiset murteet (mm. Eckerö) muistuttavat Itä-Sveanmaan murteita, kun taas itäi-

1. Ilmiötä on tutkinut perusteellisimmin Selenius (1972). Hänen mukaansa aksenttien esiintyminen noudatteli Länsi-Uudellamaalla 1970-luvun alussa foneettisesti ja morfologisesti Keski-Ruotsin murteiden mallia, mutta oppositio oli jo tuolloin häviämässä. Häviämiseen on vaikuttanut se, että vanhassa koululaitoksessa lapset pakotettiin luopumaan aksenteistaan. set murteet (mm. Brändö, Kökar, Föglö ja Kumlinge) muistuttavat eteläisen Pohjanmaan ja itäisen Turunmaan murteita. Ahvenanmaan murteista vain Eckerössä on merkityksiä erottava sana-aksentti (s. 18o). Ahvenanmaan murteiden erityispiirteitä ovat puoliavoin [œ:] (muunkin kuin /r/äänteen edellä, esim. lön), tumma [o: (esim. lat) sekä supradentaalit (s. 176-179) - kaikki piirteitä, jotka leimaavat myös ItäSveanmaan murteita (puoliavoin [œ:] rajallisemmin).

Turunmaalle (åboländska dialekter) on tyypillistä selvät murrerajat: läntisellä Turunmaalla (Iniö ja Houtskari) murteet ovat melko vahvoja ja muistuttavat eteläisen Pohjanmaan ja itäisen Ahvenanmaan murteita. Itäisen Turunmaan murteet (mm. Nauvo, Parainen ja Kemiö) ovat heikompia ja muistuttavat läntisen Uudenmaan murteita (s. 223).

Ivars toteaa, että monissa suomenruotsin murteissa näkyy suomen kielen vaikutus. Esimerkiksi Itä-Uudenmaan Pyhtäällä on monenlaista foneettista suomen vaikutusta: ylipitkiä vokaaleita ja konsonantteja (ta::la, gri::sar), tumma $/ l$, tremulanttinen /r/ sekä soinnittomia klusiileita (ägg > äkk, s. 324). Monissa murteissa, esimerkiksi Pietarsaaressa ja Loviisassa, on puolestaan runsaasti suomen sanastollista vaikutusta: många som skulle bli kaveri med en, kanske hela pårokka ('porukka'); nog var de fittiga på oss då vi pilade ('pilata') allting; han vill visa sig kåva ('kova'); kaohee ('kauhea') huvudvärk; Macke höll på och köpte sådana där makkaraperunat; sådana där kyrkliga keikkår ('keikka') (s. 375, 429). Erityisesti kiroamisessa näkyy suomen vaikutus: Loviisassa vittu vaikuttaa työntäneen altaan perinteiset ruotsalaiset voimasanat fan, djävla ja skit (s. 430). Tosin kielille yhteinen satan (saatana) on kirosanana tavallinen myös Loviisassa puhutussa ruotsissa.

Teoksessa on joitain heikkouksia ääntämisen merkitsemisessä. Tekijä käyttää esimerkeissään pääasiallisesti tavallisia aakkosia, minkä vuoksi lukijalla saat- 
taa olla vaikeuksia ymmärtää, mitä ääntämistä vaikkapa merkillä $\ddot{a}$ tarkoitetaan (esim. vävå, vatän ja fasän). Foneettisten merkkien systemaattinen käyttö olisi ratkaissut ongelman, mutta se olisi toisaalta tehnyt esimerkkien tulkitsemisen monelle lukijalle ehkä vieläkin vaikeammaksi. Foneettisten merkkien käyttöä olisi vaikeuttanut myös lähdekirjallisuuden vaihtelevat merkitsemiskäytännöt. Ääntämisen kuvaukseen liittyy muitakin puutteita. Esimerkiksi yleisääntämyksen (standardia lähellä olevan ääntämyksen) mukainen vokaali sellaisissa sanoissa kuten $k u l$ ja hus kuvataan pääluokaltaan takaiseksi, ei keskiseksi (s. 41, ylempi taulukko). Kuvaus ei täsmää sen tutkimuksen kanssa, johon kirjoittaja itse viittaa (ks. Reuter 1971). Tässä kohtaa kirjoittaja olisi ehkä voinut viitata myös suomenruotsin vokaalien akustiikkaa koskevaan tutkimukseen (Kuronen 2000). Siitä käy ilmi, että suomenruotsin yleisääntämyksen / $\mathrm{u} /$-äännettä tulee pitää keskisenä vokaalina. Useissa kohdin käytetään määritelmää "eurooppalainen u", joka on foneettisesti kummallinen. Muutamissa murteissa edelleen esiintyvää muinaisruotsin ylipitkää tavua (V:K:) kuvataan lähinnä esimerkein, joissa pitkä klusiili on sanan lopussa (esim. grö:tt, sy:dd, ro:dd). Klusiilin kuuleminen pitkänä tässä asemassa lienee kuitenkin mielikuvituksen varassa. Intonaatiota kuvatessaan Ivars ei käytä lainkaan analyysikuvia, esimerkiksi akustisia intonaatiokäyriä. Sellaiset olisivat olleet lukijalle muutamissa kohdin valaisevampia kuin intonaation sanallinen kuvaaminen.

\section{Nykysuuntauksia suomenruotsin tutkimuksen alalla}

Marika Tandefeltin toimittama teos Gruppspråk, samspråk, två språk jatkaa Ivarsin teoksen aihepiiristä kuvaamalla puhuttua suomenruotsia muista kuin murteellisista näkökulmista. Kirja muodostuu johdannosta ja 11 luvusta, jotka antavat lukijalle käsityksen siitä, millaisia painopisteitä suomenruotsin tutkimuksessa on nykyään. Artikkeleissa käsitellään muun muassa suullista vuorovaikutusta, slangia, kaksi- ja monikielistä keskustelua, kielellistä identiteettiä sekä kieliasenteita. Teemoihin liittyy suomenruotsin suhde ruotsinruotsiin ja suomeen. Kirjoittajat ovat tutkijoita suomalaisista yliopistoista, ja tämäkin teos on vertaisarvioitu. Kommentoin seuraavassa neljää artikkelia, jotka heijastelevat eri tavoin nykytutkimuksen painopisteitä.

Jan Lindström ja Camilla Wide käsittelevät artikkelissaan "Finlandssvenskt samtalsspråk" suomenruotsalaista keskustelua. Havainnot perustuvat meneillään olevaan laajaan tutkimushankkeeseen (Interaktion och variation i pluricentriska språk, 2013-2020), jossa verrataan suomen- ja ruotsinruotsin suullisen vuorovaikutuksen piirteitä pragmaattisesta näkökulmasta. Artikkelissa kuvataan oivaltavasti sitä, millaisia eroja kielimuotojen välillä on, mistä ne johtuvat ja miten vähäpätöisiltäkin tuntuvat erot saattavat olla merkityksellisiä esimerkiksi kohteliaisuuden ja puhujien välisen etäisyyden osoituksina. Suomenruotsi ja ruotsinruotsi tarjoavat vertailulle antoisan lähtökohdan, koska varieteettien väliset kulttuuris-kielelliset erot ovat pieniä mutta samanlaista taustaa vasten ilmeisiä. Muun muassa dialogipartikkelit jå ja jå-å esiintyvät vain suomenruotsissa ( $j a$ ja jo ruotsinruotsissa, s. 94). Partikkeli aj puolestaan ilmaisee suomenruotsissa sitä, että kuulija on ottanut vastaan uuden tiedon ja tehnyt siitä johtopäätöksen (esim. aj de visste ja int; s. 95). Sen sijaan ruotsinruotsissa $a j$-sanan käyttö on rajoitetumpaa: aj on ainoastaan merkki puhujan tuntemasta kivusta tai negatiivisesta yllätyksestä (esim. aj, det gjorde ont; s. 95). Sisäänhengityksellä tuotettu jo päättää suomenruotsissa joskus aiheen käsittelyn ilmoittaen, että puhujalla ei ole kysymyksestä enempää sanottavaa (s. 94). Tätä esiintyy harvoin ruotsinruotsissa. Dialogipartikkeleita nå, nåja, jo ja nog käytetään 
molemmissa varieteeteissa, mutta niiden funktiot ovat erilaisia. Esimerkiksi nå saattaa ilmaista suomenruotsissa siirtymistä uuteen aiheeseen, tuoda uuden näkökulman tai edeltää päätelmää (s. 97). Ruotsinruotsissa nå-partikkelia käytetään paljon vähemmän, ja sillä ilmaistaan puhujan kärsimättömyyttä (nå, kom nu då) tai varoitetaan kuulijaa (nå nå, sakta $i$ backarna!). Edellä mainitut esimerkit ovat vain muutamia niistä mielenkiintoisista ilmiöistä, joita kirjoittajat käsittelevät artikkelissaan. Uskon, että kirjoituksella on paljon annettavaa myös suomenkielisten keskustelujen tutkijoille.

Sofie Henricson käsittelee artikkelissaan "Svenska och finska i samma samtal" ruotsin ja suomen käyttöä rinnan samassa keskustelussa, mikä on arkipäivää monille suomenruotsalaisille. Artikkelissa näytetään, kuinka kielten vaihtelua käytetään antamaan keskustelulle monikielinen sävy tai jäsentämään sitä. Tällöin puhujat saattavat käyttää vaihtelua eri puhujien repliikkeihin viitatessaan tai se voi toimia uuden teeman esittelynä. Artikkeli auttaa lukijaa ymmärtämään niitä funktioita, joita kielten vaihtelulla voi olla suomenruotsalaisessa keskustelussa.

Kahdessa teoksen artikkelissa käsitellään slangia: suomenruotsin slangia ja suomalaista Stadin slangia. Näin saadaan näkökulma ilmiöön molempien kielten suunnasta. Mona Forsskåhl tarkastelee suomenruotsin slangin kehitystä ja erityispiirteitä artikkelissaan "Finlandssvensk slang". Hän nostaa esille Helsingin valtakeskuksena slangin leviämisessä muille suomenruotsalaisille alueille. Muillekin alueille on kuitenkin muodostunut omia, ruotsalaisperäisiä ja/tai murteeseen perustuvia slangisanoja, minkä vuoksi myös suomenruotsin slangi vaihtelee alueittain. 1900-luvun alkupuolella suomen vaikutus oli melko vähäistä suomenruotsin slangissa, mutta viime vuosikymmeninä se on kasvanut selvästi kaksikielisyyden lisääntymisen myötä.
Heikki Paunosen artikkeli "Svenska i finsk Stadislang" käsittelee ruotsin kielen vaikutusta Stadin slangissa. Paunosen historiallinen katsaus slangin syntyvaiheisiin osoittaa, millaisessa symbioosissa suomi ja suomenruotsi ovat eläneet pääkaupunkiseudulla. Stadin slangi syntyi Helsingin kaksikielisillä alueilla Kalliossa, Sörnäisissä, Hermannissa ja Vallilassa 1900-luvun alkupuolella. Stadin slangi oli Helsingin esperanto, jota alun perin puhuivat sekä suomen- että ruotsinkieliset poikaporukat, jotka jakoivat yhteisen slangisanaston yli kielirajan. Vanhassa Stadin slangissa jopa 75 \% sanoista oli peräisin ruotsista (s. 83). Paunonen antaa artikkelissaan monia mielenkiintoisia esimerkkejä siitä kielellisestä luovuudesta, joka näkyy Stadin slangin synonymiassa. Esimerkiksi kiveä tarkoittavia sanoja ovat stebari, stebbe, stebu, stena, stenari, stemu, stenu ja stibari (s. 85).

\section{Kokoava arvio}

Kirjasarjan Svenskan i Finland - i dag och i går kaksi ensimmäistä osaa, joita olen edellä arvioinut, ovat omiaan tekemään suomenruotsia tunnetuksi muunkin kuin pienehkön tutkijajoukon keskuudessa. Käsiteltävät teemat - ehkä erityisesti murteet, kieliasenteet ja monikielisyys - ovat kiinnostavia laajemmallekin lukijakunnalle. Käsittely on tutkimusperustaista mutta muutkin kuin kielentutkijat huomioivaa. Teoksiin tullaan varmasti viittaamaan lukuisissa tutkimuksissa, ja ne sopivat erinomaisesti esimerkiksi yliopistollisiksi kurssikirjoiksi.

Ivarsin teos Dialekter och småstadsspråk on vaikuttavaa luettavaa. Teos antaa kokonaisvaltaisen kuvan suomenruotsin murteiden erityispiirteistä ja kehityksestä. Kirja muodostaa laajan kaaren murteiden syntymisestä liki nykyaikaan. Pääluvut alkavat yleiskuvauksella, ja käsittely päättyy yhteenvetoon ja tulevaisuuden näkymiin. Kieliesimerkkejä, karttoja ja tietoruutuja 
käytetään lukijaystävällisesti. Yksityiskohtaisen kuvauksen vuoksi kirja on osin hakuteoksen kaltainen, mutta monin paikoin sitä voi lukea yleisesityksenäkin. Teos on tieteellisesti arvokas kuvaus muuttuvasta, osin uhanalaisesta suomenruotsalaisesta kielimaisemasta. Pääosaa kirjassa käsitellyistä murteista voi kuunnella niiden nykymuodoissa verkkosivustolla http://www.sls.fi/sv/spara-talet. Sivustolla on myös karttoja murrealueista.

Tandefeltin toimittama Gruppspråk, samspråk, två språk puolestaan muodostaa harkitun kokonaisuuden artikkeleiden järjestystä myöten. Kaikilta osin kirjassa esitelty tutkimus ei ole uutta, mutta näissä tapauksissa tuloksia pyritään suhteuttamaan uuteenkin tutkimukseen. Sopivasti populaarin otteensa ansiosta kirja sopii hyvin kielentutkimuksesta kiinnostuneille lukijoille, muillekin kuin kielitieteilijöille.

$$
\begin{array}{r}
\text { MIKKO KURONEN } \\
\text { etunimi.j.sukunimi@jyu.fi } \\
\text { Kirjoittaja on ruotsin kielen yliopiston- } \\
\text { lehtori Jyväskylän yliopistossa. }
\end{array}
$$

\section{Lähteet}

Kuronen, Mikко 200o: Vokaluttalets akustik $i$ sverigesvenska, finlandssvenska och finska. Studia Philologica Jyväskyläensia 49. Jyväskylä: Jyväskylän yliopisto.

Leinonen, Therese - Henning-LindBLOM, ANnA 2016: Gymnasieelevers åsikter om standardspråk och variation i finlandssvenskan. - Jaana Kolu, Mikko Kuronen \& Åsa Palviainen (toim.), Svenskan i Finland 16 s. 92-107. Jyväskylä: Jyväskylän yliopisto.

Reuter, Mikael 1971: Vokaler i finlandssvenskan. En instrumentell analys och ett försök till systematisering enligt särdrag. - Lars Huldén \& Carl-Eric Thors (toim.), Festskrift till Olav Ahlbäck 28.3.1971 s. 240-249. Studier i nordisk filologi 58. Skrifter utgivna av Svenska litteratursällskapet i Finland 446. Helsingfors: Svenska litteratursällskapet i Finland.

Selenius, Евв 1972: Västnyländsk ordaccent. Studier i nordisk filologi 59. Skrifter utgivna av Svenska litteratursällskapet i Finland 451. Helsingfors: Svenska litteratursällskapet i Finland.

\section{Suomenruotsi painettuna, koulussa ja yhteiskunnassa}

\author{
Marika Tandefelt (toim.): Språk i prosa \\ och press. Svenskan i Finland - i dag och i \\ går II:1. Helsingfors: Svenska litteratursäll- \\ skapet i Finland 2017. 242 s. ISBN 978-951- \\ 583-362-4.
}

Marika Tandefelt (toim.): Språk i skola och samhälle. Svenskan i Finland - i dag och i går Il:2. Helsingfors: Svenska litteratursällskapet i Finland 2017. 207 s. ISBN 978-951-583-363-1.
Marika Tandefelt on työryhmineen laatinut laajan katselmuksen Suomessa käytettävästä ruotsin kielestä. Työn tuloksena on syntynyt tähän mennessä neliosainen kirjasarja Svenskan i Finland - i dag och i går. Tulossa on vielä kaksi osaa, joiden arvioidaan ilmestyvän 2019. Työ on kestänyt ensimmäisistä hankesuunnitelmista lähtien kaikkiaan yli kymmenen vuotta, ja siihen on osallistunut 30 tutkijaa. Hankkeessa on hyödynnetty vanhoja arkisto- 